\title{
Variability of topsoil hydraulic conductivity along the hillslope transects delineated in four areas strongly affected by soil erosion
}

\author{
Antonín Nikodem, Radka Kodešová, Miroslav Fér, Aleš Klement \\ Czech University of Life Sciences Prague, Faculty of Agrobiology Food and Natural Resources, Department of Soil Science and Soil \\ Protection, Kamýcká 129, CZ-16500 Prague 6, Czech Republic. \\ * Corresponding author. Tel.: +420 224386 301. E-mail: nikodem@af.czu.cz
}

\begin{abstract}
Soil hydraulic conductivities of topsoils were studied at 5 points of the hillslope transects delineated at 4 geomorphologically diverse areas, where the original soil types (Chernozem, Luvisol and two Cambisols) were due to erosion transformed into different soil unites. Hydraulic conductivities of saturated soils and for a pressure head of $-2 \mathrm{~cm}$ were measured directly in the field using a Guelph permeameter $\left(K_{S, G P}\right)$ and mini disk tension infiltrometer $\left(K_{h=-2, M D I}\right)$, and in the laboratory using a multistep outflow method $\left(K_{s, M S O}, K_{h=-2, M S O}\right)$. While $K_{s, G P} \approx K_{s, M S O}$ in the Chernozem and Cambisol (sandy loam) regions, and $K_{s, G P}<K_{s, M S O}$ in the Luvisol and Cambisol (loam) regions. The $K_{s}$ values obtained using different methods showed different trends along the hillslope transects. The $K_{h=-2}$ values obtained using different methods showed similar trends along the transects in the Chernozem and Luvisol regions. These trends could be explained by the position within the transects (i.e., different stages of erosion/accumulation processes). No relationships were found between the $K_{h=-2}$ values in the Cambisol regions. The pressure head at an inflection point of the a soil-water retention curve was the main parameter, which appeared to associate (negative correlation) with $K_{h=-2}$ and $K_{s, M S O}$ in the Chernozem and Luvisol regions.
\end{abstract}

Keywords: Soil hydraulic properties; Guelph permeameter; Mini disk tension infiltrometer; Multistep outflow method; Aggregate stability; Retention curve inflection point.

\section{INTRODUCTION}

Soil erosion in sloping areas can significantly affect soil properties (e.g., Jakšík et al., 2015). Erosion and accumulation of a soil material in areas, which have been intensively used for farming for a long time, can even lead to a transformation of original soil types into highly diverse soil units (e.g., Zádorová et al., 2011a). There are several studies that documented that selected soil properties can be related to some of terrain attributes. A depth of topsoil horizon and organic carbon content are the most frequently studied soil properties (e.g., Florinsky et al., 2002; Jakšík et al., 2015; Lark and Beckett, 1998; Mayer et al., 2019; Moore et al., 1993; Penížek et al., 2016; Pennock, 2003; Romano and Palladino, 2002; Sarapatka et al., 2018; Vašát et al., 2017b; Zádorová and Penížek, 2018; Zádorová et al., 2011a, b, 2013, 2014, 2015). For instance, Zádorová et al. (2011a) identified the plan curvature as the main variable influencing the general soil mass redistribution in the study plot where it showed a significant relationship with the soil unit distribution and topsoil depth. On the other hand, the low control of slope in a general soil-mass redistribution at the plot was documented by its very low correlation with the soil unit redistribution and depth. In addition, for the same area, Jakšík et al. (2015) documented a negative correlation between the plan curvature and the soil organic carbon content. Structural and hydro-physical soil properties have been studied less frequently. For instance, Cantón et al. (2009), Jakšík et al. (2015) and Zádorová et al. (2011b) focused on a soil aggregate stability. While Cantón et al. (2009) did not find any correlation between the terrain attributes and aggregates stability, Jakšík et al. (2015) and Zádorová et al. (2011b) found a negative correlation between the WSA index and the plan curvature. Hydraulic conductivity and its relationship to terrain attributes was investigated by Centeno et al. (2020), Herbst et al. (2006), Papanico- laou et al. (2015), and Sobieraj et al. (2002). Whereas Sobieraj et al. (2002) showed no significant change in $K_{\mathrm{s}}$ as a function of topography, Centeno et al. (2020) found a positive correlation between $K_{s}$ and slope. Several terrain tributes (relative elevation, slope of the catchment area, radiation angle and morphometric units such as slope elements) helped to improved predictivity of $K_{s}$ using pedotransfer functions in study by Herbst et al. (2006). Papanicolaou et al. (2015) showed different patterns for different hillslopes.

Our previous study (Nikodem et al., 2021) focused on the entire soil hydraulic properties (i.e., soil water retention and soil hydraulic curves). Both soil hydraulic properties were measured on the $100-\mathrm{cm}^{3}$ undisturbed soil samples, taken at 5 points of hillslope transects delineated at 5 diverse areas, using the multistep outflow technique (MSO). Spatial and time variability of evaluated properties were assessed using the scaling factors (related to the pressure head, $\alpha_{h}$, water content, $\alpha_{\theta}$, and hydraulic conductivity, $\left.\alpha_{K}\right)$. Evaluated values were not related to the terrain attributes due to low number of sampling points. However, it was observed that at some locations (as in a Chernozem region), the spatial variability of the evaluated soil hydraulic parameters and scaling factors reflected different erosionaccumulation processes within the transects.

It has been shown among others by Gribb at al. (2004) that soil hydraulic properties evaluated directly in the field can differ from those evaluated on the undisturbed soil samples in the laboratory. The reasons are sample size (different representative volumes, which can include different pores, e.g., large gravitation pores are usually excluded when taking small-size samples), character of the experiment (e.g., dynamic infiltration experiment versus less dynamic outflow or capillary rise experiments), flow dimension (one-, two-, three-dimensional flow domain), calculation method (analytical or numerical), etc. (Gribb at al., 2004). 
Therefore, our new study focused on data obtained directly in the field using the Guelph permeameter (GP) (i.e., saturated hydraulic conductivities) and the mini disk tension infiltrometer (MDI) (i.e., unsaturated hydraulic conductivities). Measurements were performed at the same time as the samples taken in our previous study (Nikodem et al., 2021) and resulting field parameters were compared with corresponding values derived from a data presented by (Nikodem et al., 2021). In this way we attempted to find out whether trends in corresponding saturated or unsaturated soil hydraulic conductivities along the hillslope transect differed or not. Our goal was to test two hypotheses. (A) We assumed that water fluxes under ponding conditions in the case of the field experiment are dominantly impacted by gravitational pores, which occurrence and character can differ at different positions of transects. Furthermore, these pores are much more unpredictable and maybe more spatially affected than character and structure of capillary pores. Therefore, trends in the saturated hydraulic conductivities within hillslope transects obtained with different techniques (MSO and GP) should differ. (B) On the other hand, we assumed that water fluxes under unsaturated conditions should be controlled by capillary forces. Therefore, trends in unsaturated hydraulic conductivities obtained with different techniques (MSO and MDI) can be similar. In addition, our study also focused on the soil physical quality and aggregate stability within each transect and their relationship to the evaluated hydraulic conductivities. The goal was to prove third hypothesis (C) that the measured hydraulic conductivities, describing infiltration capacity, should associate with the soil physical quality and stability of soil structure.

\section{MATERIALS AND METHODS}

\section{Study areas, soil sampling, field and laboratory} measurements

The study was performed on four of five morphologically diverse study sites, which were also explored by Nikodem et al. (2021) (Table 1). Conventional tillage has long been applied at all locations. The original soil units (Calcic Chernozem, Haplic Luvisol, and two Haplic Cambisols), because of soil erosion, changed to Regosols (steep parts), and accumulated Chernozem, accumulated Luvisol, or colluvial soils, (base slope and the tributary valley), respectively (IUSS Working Group WRB, 2015). Diverse soil conditions at different localities (e.g., topographic maps and selected terrain attributes, soil type descriptions and their distributions within the entire studied areas, distributions of soil properties as a $C_{o x}$ content, $\mathrm{pH}$, soil texture, etc.) were also described by Jakšík et al. (2015, 2016), Penížek et al. (2016), Sagova-Mareckova et al. (2016), Vašát at et al. (2014, 2015a, b, 2017a, b, c), and Zádorová et al. (2011a, b,
2013, 2014, 2015). Soils within the Chernozem area (Brumovice) are the most explored followed by soils within the Luvisol area (Vidim) and both Cambisoils areas (Sedlčany and Železná).

Delineation of the sampling scheme was presented by Nikodem et al. (2021). Briefly, one representative transect (Figure 1), with the most diverse terrain attributes (elevation, slope, curvature, exposition, etc.), which caused the most variable soil properties, was delineated at each location. Five sampling points were selected at each transect, assuming that the soil at different points would be modified by the different stages of the erosion-accumulation processes (Grundwald, 2005; Miller and Schaetzl, 2015): 1. summit, 2. shoulder, 3. backslope, 4 . footslope, and 5. toeslope. The actual soil units identified in these sampling points are documented in Figure 1.

It has been documented that the soil porous systems and associated soil physical and hydraulic properties of arable soils largely vary during the year (e.g., Alletto and Coquet, 2009; Chandrasekhar et al., 2018; Jirků et al., 2013; Nikodem et al., 2021; Schwen et al., 2011a, b; Villarreal et al., 2020). Therefore, field measurements and soil sampling were performed after harvest of wheat, i.e., on the most consolidated land. Three to six GP tests were carried out at the depth of $10 \mathrm{~cm}$ to evaluate the field saturated hydraulic conductivity, $K_{s, G P}$. Ten to fifteen MDI tests were performed on the soil top (after removing $5 \mathrm{~cm}$ of the surface layer) to obtain the unsaturated hydraulic conductivities for the pressure head of $-2 \mathrm{~cm}, K_{h=-2, M D I}$. Disturbed soil samples and three undisturbed $100-\mathrm{cm}^{3}$ soil samples (soil core height of $5.1 \mathrm{~cm}$ and cross-sectional area of $\left.19.60 \mathrm{~cm}^{2}\right)$ per spot were taken in the surface layer $(0-25 \mathrm{~cm}$ and 5-10 cm, respectively). Standard laboratory tests were used to obtain the oxidable organic carbon content $\left(C_{o x}\right)$ and particle size distribution by Nikodem et al. (2021) (Figure 2). The MSO method was used to evaluate the soil hydraulic properties (Nikodem et al., 2021).

In addition, an aggregate stability was assessed using the WSA index proposed by Nimmo and Perkins (2002). Four grams of air-dry soil aggregates of the size of $2-5 \mathrm{~mm}$ was sieved (sieve $0.25 \mathrm{~mm}$ ) for $3 \mathrm{~min}$ in distilled water. Aggregates remaining on the sieve were next sieved in sodium hexametaphoshate until only sand particles remained on the sieve. The index of water-stable aggregates, WSA (-), (Figure 2) was then determined as:

$$
W S A=\frac{W_{d s}}{\left(W_{d s}+W_{d w}\right)}
$$

where $W_{d s}(\mathrm{M})$ is the weight of aggregates dispersed in dispersing solution and $W_{d w}(\mathrm{M})$ is the weight of aggregates dispersed in distilled water.

Table 1. Description of study sites adopted from Nikodem et al. (2021).

\begin{tabular}{|c|c|c|c|c|c|c|c|c|c|c|}
\hline \multirow[b]{2}{*}{ Locality } & \multirow{2}{*}{$\begin{array}{l}\text { Average } \\
\text { annual } \\
\text { precipitations } \\
(\mathrm{mm})^{\mathrm{a}}\end{array}$} & \multirow{2}{*}{\begin{tabular}{|l|} 
Average \\
annual \\
temperatures \\
$\left({ }^{\circ} \mathrm{C}\right)^{\mathrm{a}}$
\end{tabular}} & \multirow[b]{2}{*}{$\begin{array}{l}\text { Parent } \\
\text { material }\end{array}$} & \multirow[b]{2}{*}{$\begin{array}{l}\text { Original } \\
\text { soil unit }\end{array}$} & \multirow[b]{2}{*}{$\begin{array}{l}\text { Soil } \\
\text { texture }\end{array}$} & \multicolumn{2}{|c|}{ Transect } & \multirow[b]{2}{*}{$\begin{array}{l}\text { Sampling } \\
\text { date }\end{array}$} & \multirow{2}{*}{$\begin{array}{l}\text { Field soil } \\
\text { water } \\
\text { content } \\
\left(\mathrm{cm}^{3} \mathrm{~cm}^{-3}\right)\end{array}$} & \multirow[b]{2}{*}{$\begin{array}{l}\text { Bulk } \\
\text { density } \\
\left(\mathrm{g} \mathrm{cm}^{-3}\right)\end{array}$} \\
\hline & & & & & & $\begin{array}{l}\text { Length } \\
\text { (m) }\end{array}$ & $\begin{array}{l}\begin{array}{l}\text { Altitude } \\
\text { difference } \\
(\mathrm{m})\end{array} \\
\end{array}$ & & & \\
\hline Brumovice & $500-600$ & $9.0-10.0$ & Loess & $\begin{array}{l}\text { Calcic } \\
\text { Chernozem }\end{array}$ & \begin{tabular}{|l|} 
Silt loam \\
Loam $\left(1^{\text {st }}\right)$ \\
\end{tabular} & 90 & 13 & 15. 08. 2011 & $0.24 \pm 0.01$ & $1.44 \pm 0.04$ \\
\hline Vidim & $550-650$ & $7.0-8.0$ & Loess & $\begin{array}{l}\text { Haplic } \\
\text { Luvisol }\end{array}$ & Silt loam & 86 & 9 & 01. 08. 2012 & $0.32 \pm 0.01$ & $1.43 \pm 0.02$ \\
\hline Sedlčany & $550-650$ & $7.0-8.0$ & $\begin{array}{l}\text { Granodiorite } \\
\text { and shale }\end{array}$ & $\begin{array}{l}\text { Haplic } \\
\text { Cambisol }\end{array}$ & \begin{tabular}{|l|} 
Sandy loam \\
Loam $\left(3^{\text {rd }}\right)$
\end{tabular} & 86 & 12.6 & 8. 08. 2012 & $0.26 \pm 0.01$ & $1.40 \pm 0.05$ \\
\hline Železná & $450-550$ & $7.0-8.5$ & Shale & $\begin{array}{l}\text { Haplic } \\
\text { Cambisol }\end{array}$ & Loam & 170 & 22 & 14. 08.2013 & $0.36 \pm 0.01$ & $1.44 \pm 0.05$ \\
\hline
\end{tabular}

${ }^{a}$ Data monitored by the Czech Hydrometeorological Institute during 1961-2013 (http://portal.chmi.cz/historicka-data/pocasi/mesicni-data/mesicni-data-dlez.-123-1998-Sb) 

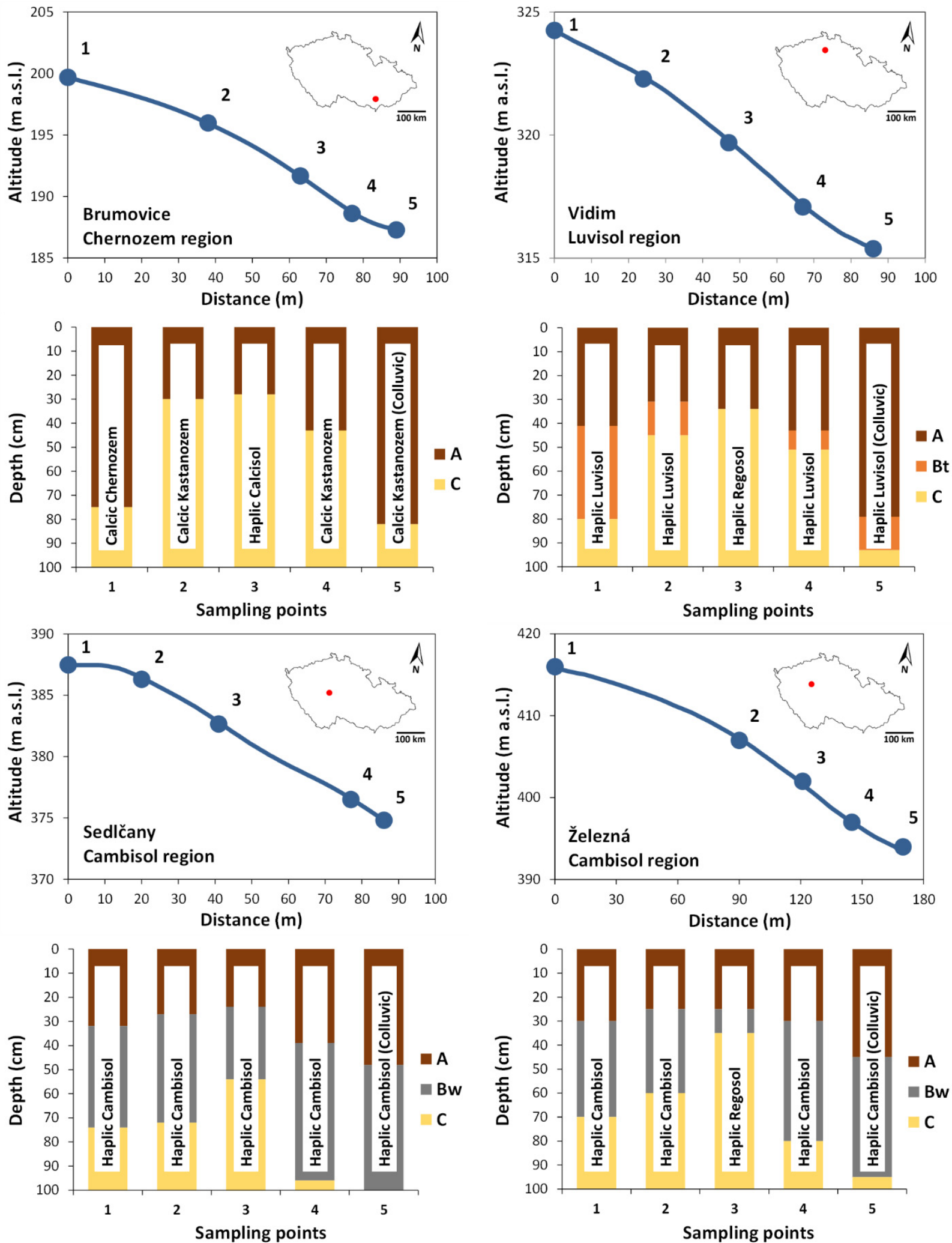

Fig. 1. Localization of studied sites, transects delineated at each location (characterized by altitude), and soil types (characterized by their diagnostic horizons to a depth of $1 \mathrm{~m}$ ) developed at the studied points. Numbers 1, 2, 3, 4 and 5 indicate sampling points.

Finally, undisturbed $90-\mathrm{cm}^{3}$ soil blocks $(3 \mathrm{~cm} \times 3 \mathrm{~cm} \times 10$ $\mathrm{cm}$ ) were taken from the depth of 5-8 $\mathrm{cm}$, which were used to prepare thin vertical soil sections according to the methods of Stoops (2003). The final thin section size was $1.5 \mathrm{~cm} \times 2 \mathrm{~cm}$.
Images (Figure 3) were obtained with the OLYMPUS BX51 polarization microscope equipped with the OLYMPUS DP70 digital camera (using software Deep Focus 3.0) at a $2 \times$ magnification and a resolution of $300 \mathrm{dpi}$. 

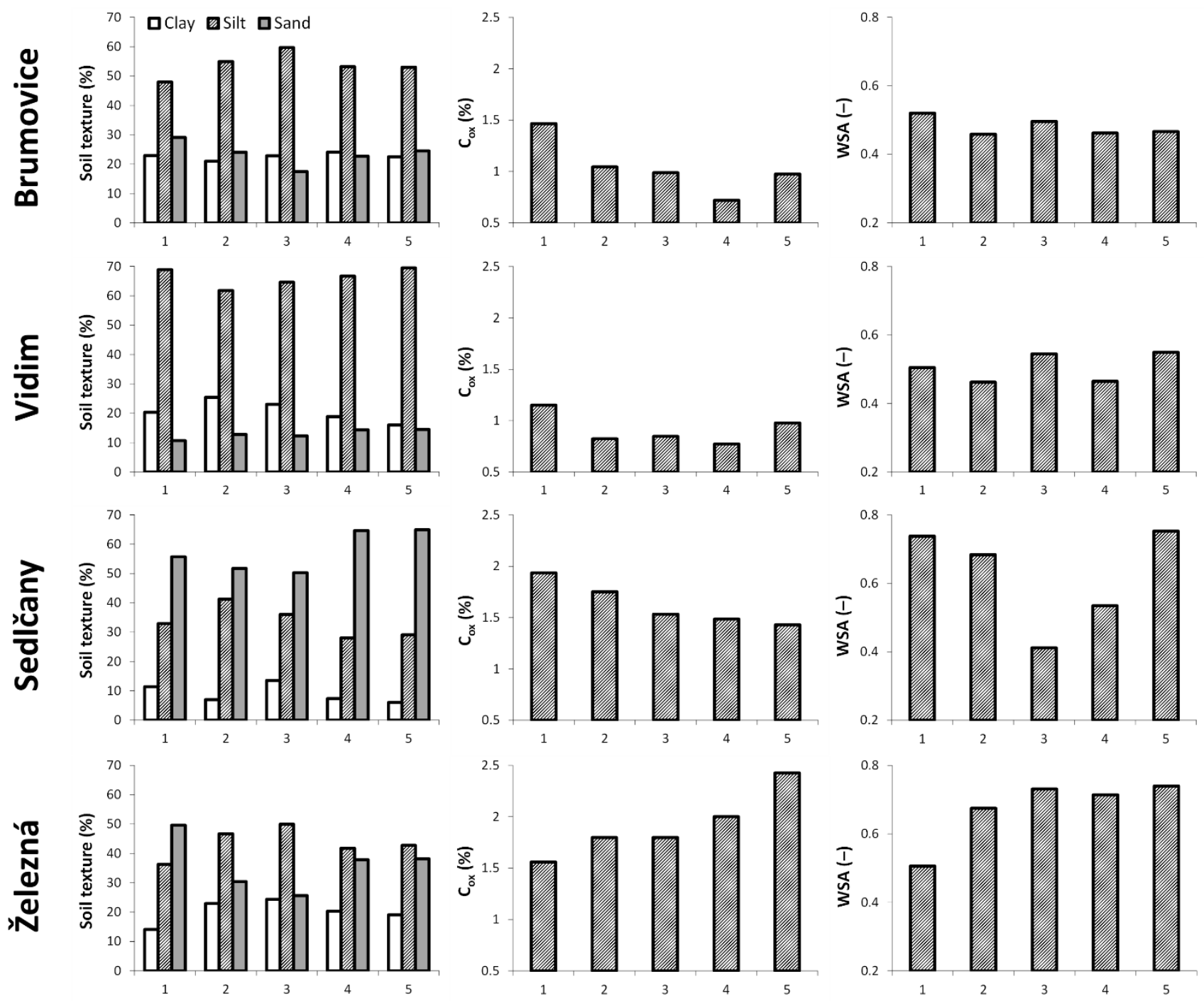

Fig. 2. Soil texture (clay, silt and sand content) (Nikodem et al., 2021), organic carbon content $\left(C_{o x}\right)$ (Nikodem et al., 2021) and WSA (water stable aggregates) index within transects delimitated at each location, i.e., Brumovice (Chernozem area, loess), Vidim (Luvisol area, loess), Sedlčany (Cambisol area, granodiorite and shale) and Železná (Cambisol area, shale). Numbers indicate sampling points: $1-$ summit, 2 - shoulder, 3 - backslope, 4 - footslope, 5 - toeslope.

\section{Hydraulic conductivities evaluated using the Guelph permeameter method}

The Guelph permeameter was used in the field to measure the water flux under the well ponding condition. The depth of the drilled well was $10 \mathrm{~cm}$, the well radius was $3 \mathrm{~cm}$, and the well ponding depth was $5 \mathrm{~cm}$. The standard procedure recommended in the GP manual (Soilmoisture Equipment Corp., 2012) was used to prepare the infiltration well. The well was drilled using a soil auger, then shaped with a sizing auger, and finally well brush was applied to remove the smear layer on the well sides. The tests with GP lasted at least 45 minutes. The saturated hydraulic conductivity, $K_{s, G P}\left(\mathrm{~L} \mathrm{~T}^{-1}\right)$, was calculated according to Elrick et al. (1989) and Reynolds et al. (2002):

$K_{s, G P}=\frac{C Q}{2 \pi H^{2}+\pi a^{2} C+2 \pi H / \alpha_{G}}$ where $Q$ is the steady water flux $\left(\mathrm{L}^{3} \mathrm{~T}^{-1}\right), H$ is the ponding depth (L) $(5 \mathrm{~cm}), a$ is the well radius (L) $(3 \mathrm{~cm})$ and $\alpha_{G}\left(\mathrm{~L}^{-1}\right)$ is the constant in the Gardner equation (1958) describing relationship between the unsaturated hydraulic conductivity, $K\left(\mathrm{~L} \mathrm{~T}^{-1}\right)$, and the pressure head, $h(\mathrm{~L})$ :

$K(h)=K_{S} \exp \left(\alpha_{G} h\right)$

where $K_{s}\left(\mathrm{~L} \mathrm{~T}^{-1}\right)$ is the saturated hydraulic conductivity. Values of $\alpha_{G}$ characterizing soil structure were measured by Reynolds and Elrick (1991) for sand $0.36 \mathrm{~cm}^{-1}$, loam $0.12 \mathrm{~cm}^{-1}$ and clay $0.04 \mathrm{~cm}^{-1}$. Finally, $C$ is the dimensionless constant calculated for $\alpha_{G}=0.12 \mathrm{~cm}^{-1}$ (loam) according to the following equation (Zhang et al., 1998):

$C=\frac{H / a}{2.074+0.093(H / a)}$ 


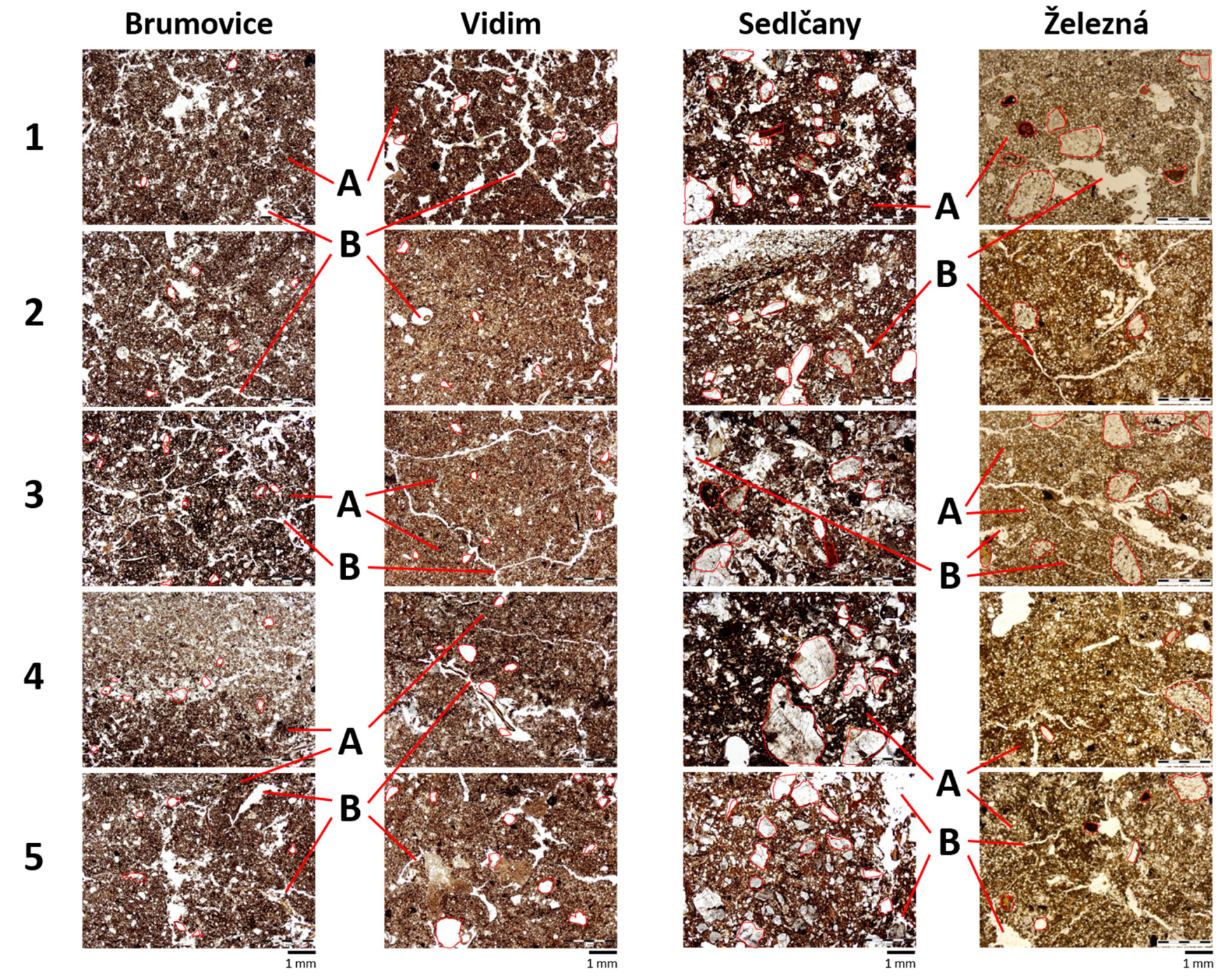

Fig. 3. Micromorphological images of the soil samples taken within transects delimitated at each location, i.e., Brumovice (Chernozem area, loess), Vidim (Luvisol area, loess), Sedlčany (Cambisol area, granodiorite and shale) and Železná (Cambisol area, shale). Numbers indicate sampling points: 1 - summit, 2 - shoulder, 3 - backslope, 4 - footslope, 5 - toeslope. A - soil aggregates, B - pores, small rock fragments and large grains are surrounded by red.

\section{Hydraulic conductivities evaluated using the mini disk tension infiltrometer method}

The mini disk tension infiltrometer with a disk radius of 2.22 $\mathrm{cm}$ (Meter Group, 2020) was used to measure the cumulative water infiltration under unsaturated conditions. Pressure head was always set at the value of $-2 \mathrm{~cm}$ according to Watson and Luxmoore (1986) as limit between gravitational and capillary pores. This value of pressure head is also standardly set when the various mini disk infiltrometers are used to evaluate soil water repellency (e.g., Fér et al., 2020; Lichner et al., 2020; Sándor et al., 2021; Sepehrnia et al., 2020). The close contact between the carefully levelled soil surface and disk was ensured by a $1 \mathrm{~mm}$ layer of the same soil, sieved through a 2-mm sieve, as proposed by Kodešová et al. (2010, 2011). The infiltration test lasted at least $30 \mathrm{~min}$. The unsaturated hydraulic conductivity, $K_{h=-2, M D I}\left(\mathrm{~L} \mathrm{~T}^{-1}\right)$, for $h=h_{0}=-2 \mathrm{~cm}$ was calculated according to Zhang (1997). Cumulative infiltration $I(\mathrm{~L})$ in time $t(\mathrm{~T})$ was fitted using the following equation:

$I=C_{1} t+C_{2} t^{1 / 2}$
$C_{1}\left(\mathrm{~L} \mathrm{~T}^{-1}\right)$ and $C_{2}\left(\mathrm{~L} \mathrm{~T}^{-1 / 2}\right)$ are the parameters related to the hydraulic conductivity $K\left(h_{0}\right)$ and sorptivity $S\left(h_{0}\right)$ :

$C_{1}\left(h_{0}\right)=\mathrm{A}_{1} K\left(h_{0}\right)$ and $C_{2}\left(h_{0}\right)=A_{2} S\left(h_{0}\right)$

where $A_{1}$ and $A_{2}$ are the dimensionless constants. The $K\left(h_{0}\right)=$ $K_{h}=-2, M D I, Z$ value was calculated using Eq. (6) and following expressions for $A_{1}$ constant:

$A_{1}=\frac{11.65\left(n^{0.1}-1\right) \exp \left[2.92(n-1.9) \alpha h_{0}\right]}{\left(\alpha r_{0}\right)^{0.91}}$ for $n \geq 1.9$

$\mathrm{A}_{1}=\frac{11.65\left(n^{0.1}-1\right) \exp \left[7.5(n-1.9) \alpha h_{0}\right]}{\left(\alpha r_{0}\right)^{0.91}} \quad$ for $1.35<n<1.9$

$A_{1}=\frac{11.65\left(n^{0.82}-1\right) \exp \left[34.65(n-1.19) \alpha h_{0}\right]}{\left(\alpha r_{0}\right)^{0.6}}$ for $n<1.35$

where $\alpha\left(\mathrm{L}^{-1}\right)$ and $n$ (dimensionless) are the van Genuchten parameters (parameters obtained from the MSO experiment, Nikodem et al., 2021), $r_{0}$ is the disk radius $(2.22 \mathrm{~cm})$ and $h_{0}$ is the applied pressure head $(-2 \mathrm{~cm})$. 


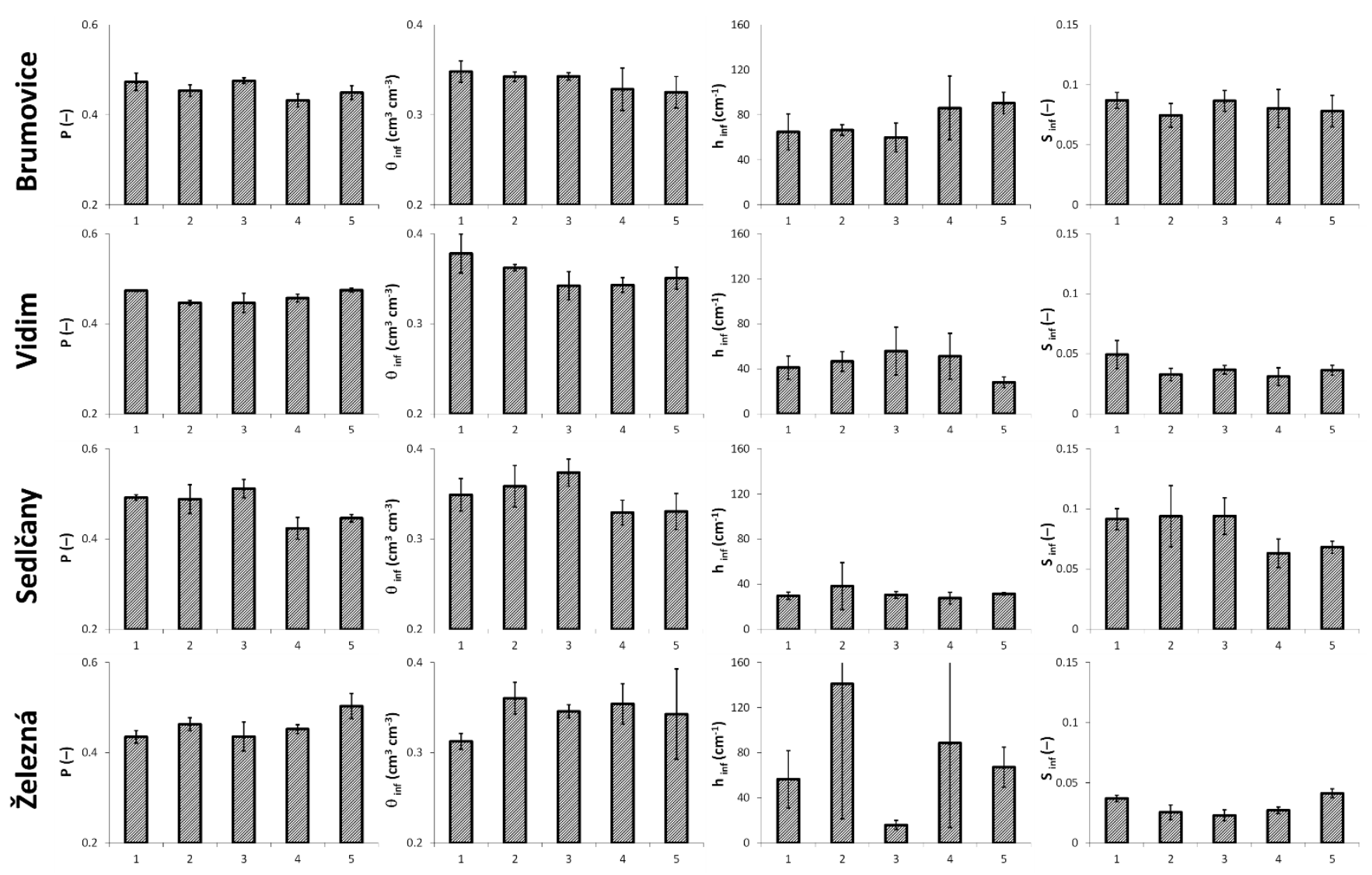

Fig. 4. Porosity $(\mathrm{P})$, and characteristics of the inflection point of the soil-water retention curve: soil water content $\left(\theta_{I N F}\right)$, pressure head $\left(h_{I N F}\right)$ and curve slope $\left(S_{I N F}\right)$; within transects delimitated at each location, i.e., Brumovice (Chernozem area, loess), Vidim (Luvisol area, loess), Sedlčany (Cambisol area, granodiorite and shale) and Železná (Cambisol area, shale). Values were calculated from the soil hydraulic parameters obtained using the MSO method presented by Nikodem et al. (2021). Numbers indicate sampling points: 1 - summit, 2 - shoulder, 3 - backslope, 4 - footslope, 5 - toeslope. Graphs show average values and standard deviations (error bars).

Other method proposed by Wooding (1968) was also used to evaluate the unsaturated hydraulic conductivity $K\left(h_{0}\right)=$ $K_{h}=-2, M D I, W$. The following algebraic approximation of steady state unconfined infiltration rates into soil from a circular source of radius $r_{0}(\mathrm{~L})$ was assumed:

$Q=\pi r_{0}^{2} K\left(h_{0}\right)\left(1+\frac{4}{\pi r_{0} \alpha_{G}}\right)$

where $Q$ is the steady water flux $\left(\mathrm{L}^{3} \mathrm{~T}^{-1}\right)$, $r_{0}$ is the disk diameter $(2.22 \mathrm{~cm}), h_{0}$ is the applied pressure head $(-2 \mathrm{~cm}), \alpha_{G}(=0.12$ $\mathrm{cm}^{-1}$ ) is the constant characterizing soil structure (Equation 3$)$.

\section{Hydraulic properties measured using the multistep outflow method}

Soil water retention curves, $\theta(h)$, and soil hydraulic curves, $K(\theta)$, were evaluated in the laboratory with undisturbed $100-\mathrm{cm}^{3}$ soil samples placed in Tempe cells using the MSO test (van Dam et al., 1994). Detail procedure and results were presented by Nikodem et al. (2021). In this study, the soil hydraulic properties were described by the analytical expressions proposed by van Genuchten (1980):

$\begin{array}{ll}\theta_{e}=\frac{\theta(h)-\theta_{r}}{\theta_{s}-\theta_{r}}=\frac{1}{\left(1+|\alpha h|^{n}\right)^{m}}, & \\ \theta_{e}=1, & h \geq 0\end{array}$

$$
\begin{aligned}
& K(\theta)=K_{s, M S O} \theta_{e}^{l}\left[1-\left(1-\theta_{e}^{1 / m}\right)^{m}\right]^{2}, \quad h<0 \\
& K(\theta)=K_{s, M S O}, \quad h \geq 0
\end{aligned}
$$

where $\theta$ is the soil water content $\left(\mathrm{L}^{3} \mathrm{~L}^{-3}\right), \theta_{e}$ is the effective soil water content (dimensionless), $\theta_{r}$ and $\theta_{s}$ are the residual and saturated soil water contents $\left(\mathrm{L}^{3} \mathrm{~L}^{-3}\right)$, respectively, $\alpha$ is the reciprocal of the air entry pressure $\left(\mathrm{L}^{-1}\right), n$ (dimensionless) is related to the slope of the retention curve at the inflection point, $m=1-1 / n$ (dimensionless). $K_{s, M S O}$ is the saturated hydraulic conductivity $\left(\mathrm{L} \mathrm{T}^{-1}\right)$, and $l$ is the pore-connectivity parameter (dimensionless), which was set to 0.5 (Mualem, 1976). Here we present only the resulting $K_{S, M S O}$ values, which are compared with the $K_{s, G P}$ values. For comparison with the values obtained using MDI, $K_{h=-2, M D I}$, the hydraulic conductivity values corresponding to the pressure head of $-2 \mathrm{~cm}$ were also calculated, $K_{h=-2, M S O}$.

In addition, the parameters of the inflection points (Figure $4)$, i.e., soil water content $\left(\theta_{I N F}\right)$, the pressure head $\left(h_{I N F}\right)$ and curve slope $\left(S_{I N F}\right)$, of the soil water retention curves were computed according to Dexter (2004a, b, c) and Dexter and Czyz (2007):

$\theta_{I N F}=\left(\theta_{s}-\theta_{r}\right)\left(1+\frac{1}{m}\right)^{-m}+\theta_{r}$

$h_{I N F}=\frac{1}{\alpha}\left(\frac{1}{m}\right)^{\frac{1}{n}}$ 
$S_{I N F}=-n\left(\theta_{s}-\theta_{r}\right)\left(1+\frac{1}{m}\right)^{-(1+m)}$

These parameters can be used to assess a physical quality of soils (e.g., Dexter, 2004a, b, c; Fér et al., 2016, 2018, 2020; Jirků et al., 2013; Pavlů et al., 2021): if $S_{I N F}<0.02$ PQS is very poor, if $0.02 \leq S_{I N F}<0.035 \mathrm{PQS}$ is poor, if $0.035 \leq S_{I N F}<0.05$ PQS is good, and if $0.05 \leq S_{I N F}$ the physical quality of soil (PQS) is very good. However, it should be noted that different methods used for measuring the soil water retention curves can lead to different shapes of these curves (e.g., Gribb et al., 2004; Fér et al., 2018) and thus to different characteristics of the inflection point (Fér et al., 2018). Therefore, the evaluated values are rather suitable for comparing soil quality on a given area or transect than for a general assessment of a soil physical quality. The undisturbed soil samples were also used to evaluate soil porosity (Figure 4 ).

\section{Statistical analyses}

The average values and their standard deviations were calculated for all measured soil properties at each sampling point. Simple correlations between the average values of the hydraulic conductivities and other soil properties were assessed using the Pearson product moment correlation coefficient and p-value, which tests the statistical significance of the estimated correlations. Linear regressions were also used to obtain relationships between the corresponding hydraulic conductivities. Analyses were performed using the statistical software Statistica (StatSoft Inc., 2013).

\section{RESULTS AND DISCUSSION \\ Hydraulic conductivities of soils developed on loess substrates}

The resulting soil hydraulic conductivities obtained using different methods are shown in Figure 5. Results for the Brumovice locality (the Chernozem region) show that while the $K_{s}$ values at the $2^{\text {nd }}, 3^{\text {rd }}$ and $4^{\text {th }}$ sampling points obtained with different methods are similar, the $K_{s}$ values at the $1^{\text {st }}$ and $5^{\text {th }}$ sampling points considerably differ. The values obtained using the MSO method are much larger than those measured with the GP method. In addition, the $K_{s, G P}$ values are considerably lower than the $K_{h=-2, M D I}$ values calculated using both methods. This is in contrast with expectations that: a) $K_{s}$ should be larger than $K$ for the pressure head of $-2 \mathrm{~cm}$; b) $K_{s}$ measured under the well ponding conditions can be larger than $K_{s}$ from MSO due to an influence of a large gravitational pores on water fluxes in the field, which are usually excluded in the small undisturbed soil samples (Gribb at al., 2004). Initially increasing trend followed by decreasing trend in $K_{s, G P}$ with decreasing elevation (i.e., increasing no. of sampling point) corresponds to the trend in the silt content (Figure 2). It can be hypostatized that despite precaution taken during the well drilling the soil structure was more disturbed at the $1^{\text {st }}$ and $5^{\text {th }}$ points (lower and higher silt and sand fraction, respectively) and, probably, there was even a greater smoothing of the walls due to presence of clay than that at other sampling points, that reduced water flux into the soil. On the other hand, the trend in $K_{S, M S O}$ corresponds to the soil structure documented in Figure 3. For instance, while the higher $K_{s, M S O}$ values (Figure 5) associate with a soil aggregation at the $1^{\text {st }}$ and $3^{\text {rd }}$ point (Figure 3 ), the lowest $K_{s, M S O}$ values at the $4^{\text {th }}$ point can be explained by a homogeneous structure at this point.

Results for the Vidim locality (the Luvisol region) show that the $K_{s, M S O}$ values are mostly higher than the $K_{s, G P}$ values, but the
$K_{s, G P}$ values are higher than the $K_{h=-2, M D I}$ values. The trends in the $K_{s, G P}$ values and silt content are, except at the $5^{\text {th }}$ point, similar. In this case, the main factor, which likely reduced water fluxes in the field, was the destruction of the soil structure. Similar results (i.e., $K_{s, M S O}>K_{s, G P}$ ) were also obtained for all horizons of the Haplic Luvisol by Kodešová et al. (2011). The lower $K_{s, G P}$ values than the $K_{h=-2, M D I}$ values were also measured in topsoil, but the larger $K_{s, G P}$ values than the $K_{h=-2, M D I}$ values were measured in the subsurface horizons due to well-developed prismatic structure preserved by clay coating.

Trends in the $K_{s, G P}$ and $K_{s, M S O}$ values documented for the $2^{\text {nd }}$, $3^{\text {rd }}$ and $4^{\text {th }}$ sampling points at the Vidim locality are similar, which is consistent with a similarity of trends in these values for the Brumovice locality. This indicates that behavior of the soil materials during their testing at the summit (by erosion least affected soils) and toeslope (accumulated material from upslope positions) considerably differed from each other and from those at the sloping part of the transects.

When comparing the resulting $K_{h=-2, M S O}$ and $K_{h=-2, M D I}$ values, it is evident that values do not considerably differ. The $K_{h=-2, M D I, Z}$ values are closer to the $K_{h=-2, M S O}$ values than the $K_{h=-2, M D I, W}$ values. All $K_{h=-2}$ values show similar trends along the transects. Therefore, the liner relationships between different values $K_{h=-2}$ could be detected (Table 2). However, the pvalues, which are mostly higher than 0.05 , except the first and last relationships, do not indicate statistically significant correlations at the $95.0 \%$ confidence level and higher. In addition, Figure 5 shows that the variability of the evaluated hydraulic conductivities at each sampling point is large, with some exemptions, which adds additional uncertainty to the analysis.

It should be also noted that while the $K_{h=-2}$ values measured at the Brumovice locality decrease with the elevation, the $K_{h=-2}$ values measured at the Vidim locality increase with the elevation. This may indicate aggravation of soil-pore systems due to the erosion and accumulation processes (i.e., not favorable conditions for soil structure preservation and formation - frequent material loos, not enough time for a development of a soil structure in a periodically sedimented soil material, etc.) at the Brumovice Locality. At the Vidim locality, the opposite trend could be explained by the fact that topsoil at sloping parts included material from the illuvial Bt horizon, which is typical by the development of clay coating and infillings, and the formation of relatively stable soil aggregates (Kodešová et al., 2009) (Figure 4), which could modify soil-pore systems (Nikodem et al., 2021). The topsoil at the toeslope and partly also footslope was amended with eroded soil material from the upslope surface layers (i.e., material of better quality from the original A horizon mixed with some material from the Bt horizon from eroded parts of the transect) (Zádorová et al., 2014, 2015), which could lead to better conditions for the development of soil structure (Nikodem et al., 2021).

\section{Hydraulic conductivities of soils developed on granodiorite and shale substrates}

The resulting $K_{s, G P}$ and $K_{s, M S O}$ values for the Sedlčany locality (the Cambisol region) show again different trends along the transect. Values for the $2^{\text {nd }}, 3^{\text {rd }}$ and $5^{\text {th }}$ sampling points are similar, $K_{s, G P}>K_{s, M S O}$ at $1^{\text {st }}$ and $K_{s, G P}<K_{s, M S O}$ at the $4^{\text {th }}$ sampling point. The decreasing trend in $K_{s, G P}$ with the elevation can be explained by the decreasing bulk density (Figure 4) and increasing fraction of large grains (Figure 3). The resulting $K_{s, G P}$ values for the Železná locality (the Cambisol region) are mostly considerably lower than the $K_{s, M S O}$ values. Figures 2 and 3 show that that soils at the Železná locality contained more 


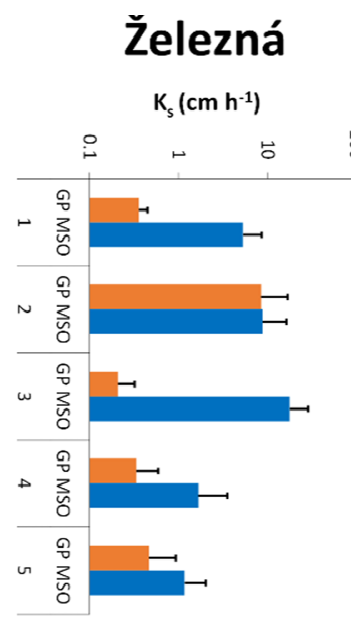

\section{Sedlčany}

Vidim

\section{Brumovice}
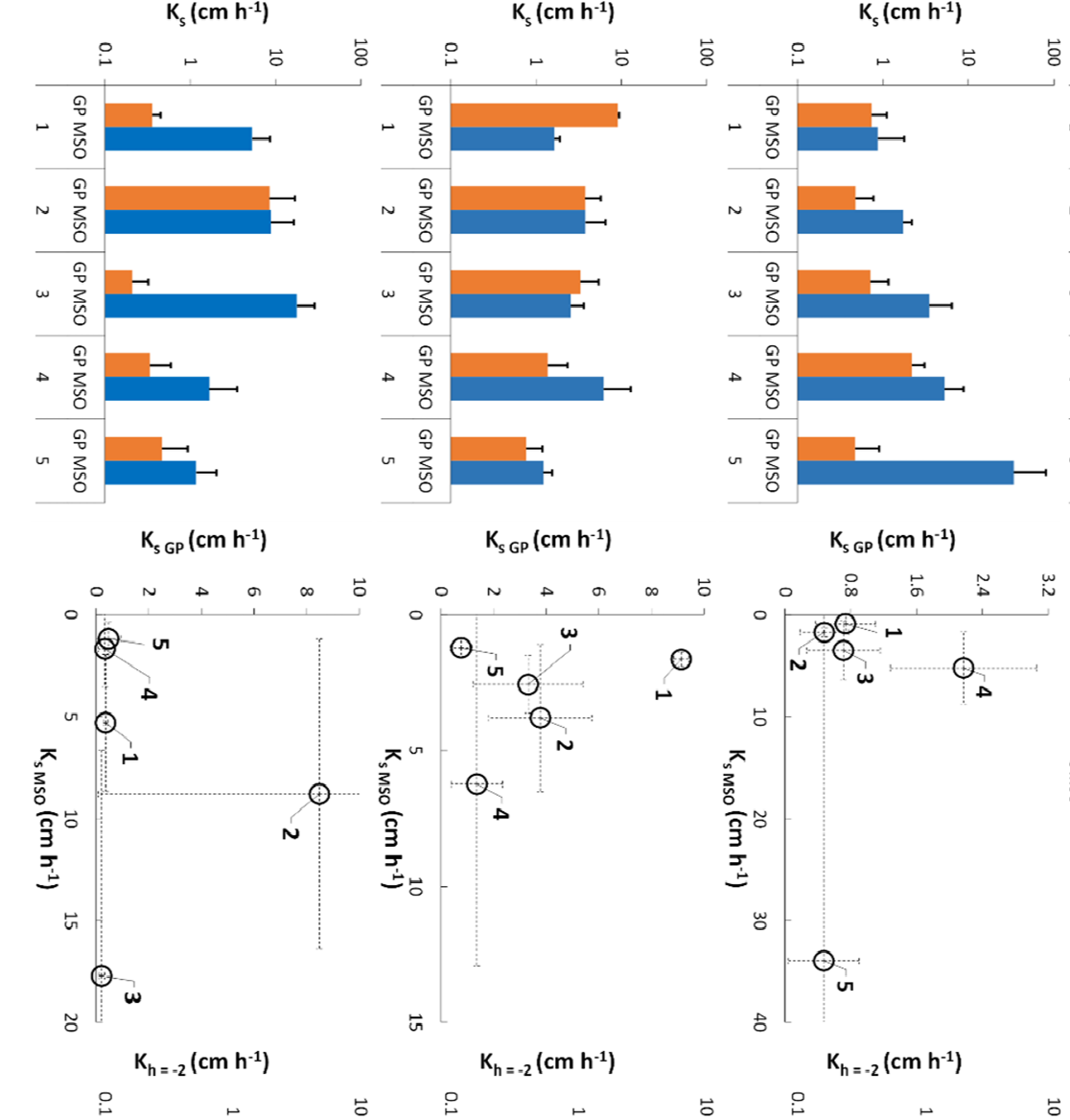

$\stackrel{5}{\circ} \stackrel{\mathrm{K}_{\mathrm{s}}\left(\mathrm{cm} \mathrm{h}^{-1}\right)}{\circ} \stackrel{\circ}{\circ}$
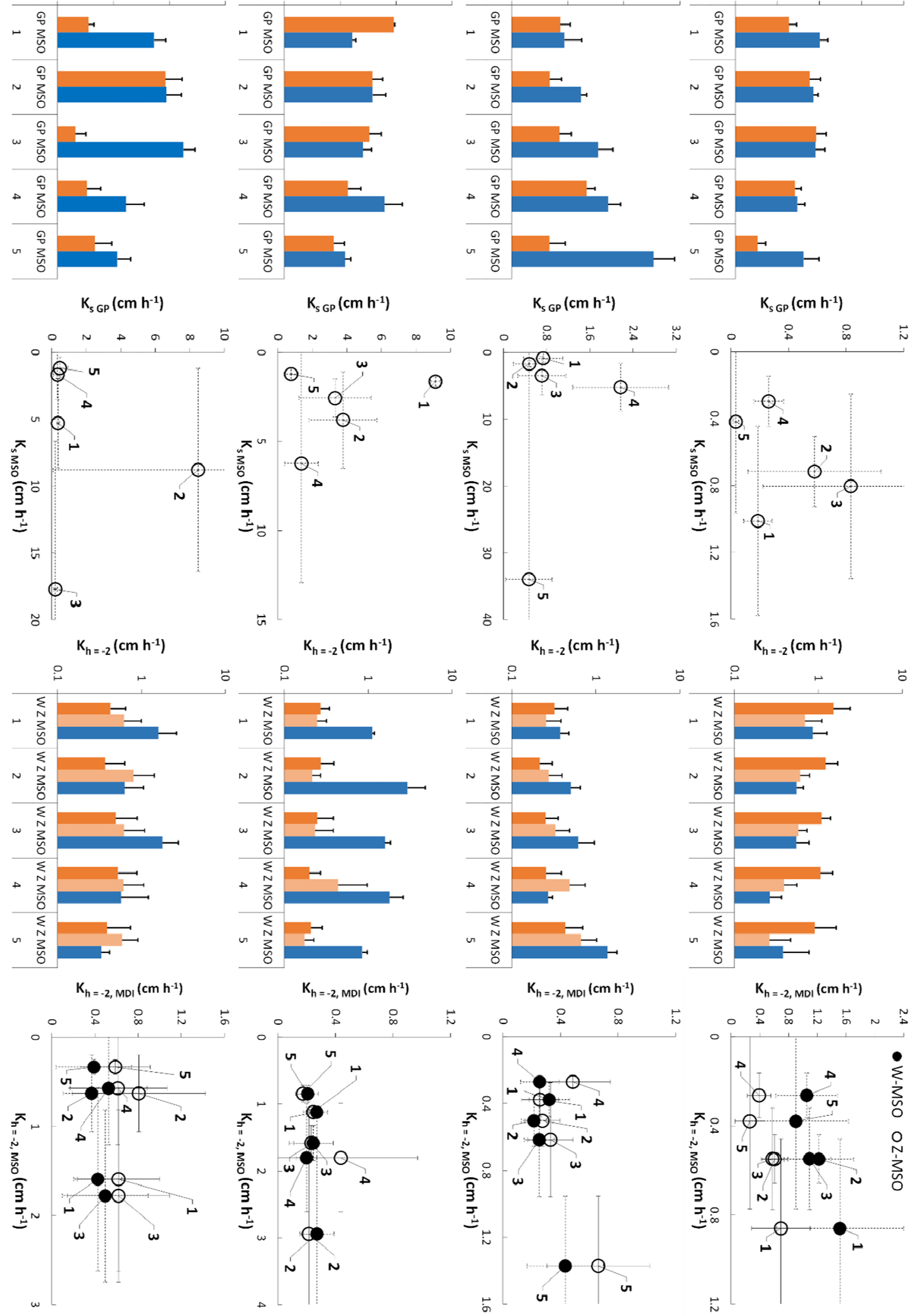

Fig. 5. Saturated hydraulic conductivities measured using the Guelph permeameter $\left(K_{S, G P}\right)$ and the multistep outflow method ( $\left.K_{s, M S O}\right)$, and hydraulic conductivities for the pressure head of $-2 \mathrm{~cm}$ measured using the mini disk tension infiltrometer and Wooding $\left(K_{h=-2, M D I, W}\right)$ or Zhang $\left(K_{h=-2, M D I, Z)}\right.$ method, and the multistep outflow method ( $\left.K_{h=-2, M D I, M S O}\right)$ for Brumovice (Chernozem area, loess), Vidim (Luvisol area, loess), Sedlčany (Cambisol area, granodiorite and shale) and Železná (Cambisol area, shale), and relationships between corresponding values. GP Guelph permeameter, MDI - mini disk tension infiltrometer, W - Wooding, Z - Zhang, MSO - multistep outflow. Numbers indicate sampling points: 1 - summit, 2 - shoulder, 3 - backslope, 4 - footslope, 5 - toeslope. Graphs show average values and standard deviations (error bars). 
Table 2. Relationships between the hydraulic conductivities for the pressure head of $-2 \mathrm{~cm}$ obtained using the mini disk tension infiltrometer and Wooding $\left(K_{h=-2, M D I, W}\right)$ or Zhang $\left(K_{h=-2, M D I, Z)}\right.$ method, and the multistep outflow method $\left(K_{h=-2, M D I, M S O}\right)$, coefficients of determinations $\left(\mathrm{R}^{2}\right)$ and $\mathrm{p}$-values.

\begin{tabular}{|l|l|l|l|l|}
\hline Location & Regression equation & $\mathrm{R}^{2}$ & $\mathrm{p}$ & Number of points \\
\hline \multirow{3}{*}{ Brumovice } & $K_{h=-2, M D I, W}=0.91 K_{h=-2, M S O}+0.69$ & 0.79 & 0.045 & 5 \\
\cline { 2 - 5 } & $K_{h=-2, M D I, Z}=0.65 K_{h=-2, M S O}+0.17$ & 0.70 & 0.075 & 5 \\
\hline \multirow{3}{*}{ Vidim } & $K_{h=-2, M D I, W}=0.16 K_{h=-2, M S O}+0.20$ & 0.65 & 0.10 & 5 \\
\cline { 2 - 6 } & $K_{h=-2, M D I, Z}=0.29 K_{h=-2, M S O}+0.22$ & 0.53 & 0.16 & 5 \\
\cline { 2 - 6 } & $K_{h=-2, M D I, Z}=0.42 K_{h=-2, M S O}+0.08$ & 0.99 & 0.003 & $4^{\mathrm{a}}$ \\
\hline
\end{tabular}

${ }^{\text {a }}$ data for the $4^{\text {th }}$ sampling point was excluded

clay particles and their structure was more compact than soils at the Sedlčany locality. Thus, a possible soil structure deformation and smearing of well walls had a greater impact on water fluxes at the Železná locality than at the Sedlčany locality. This explanation is also supported by the fact that, while $K_{s, G P}>K_{h=-2, M D I}$ at the Sedlčany locality, $K_{s, G P}<K_{h=-2, M D I}$ at the Železná locality. Similar findings were documented by Fér et al. (2016), who evaluated hydraulic properties of different horizons of two Haplic Cambisols. While in soils of similar texture to that at the Sedlčany locality $K_{s, G P}>K_{s, M S O}$, in soils of similar texture to that at the Železná locality $K_{s, G P}<K_{s, M S O}$ and $K_{s, G P}<K_{h=-2, M D I}$. The resulting $K_{h=-2, M S O}$ values at both localities show larger variability than the $K_{h=-2, M D I}$ values. No relationship was detected between values obtained using these different methods. It is possible that the original soil-pore structure of both Cambisols was more modified (unified) during the preparation of the soil surface for the infiltration experiments than the soil-pore structure of both soils developed on loess. Evaluated $K_{h=-2}$ did not show any trends along the hillslope transects, which is consistent with findings presented by Nikodem et al (2021).

\section{Soil physical quality}

Figure 2 shows a slightly decreasing trend in the WSA index with the elevation at the Brumovice location (the negative influence of erosion/accumulation processes) (e.g., Jakšík et al., 2015; Zádorová et al., 2011b), increasing trend at the Vidim location (the positive influence of clay coating (e.g., Kodešová et al., 2009) and accumulation of the organic matter at the toeslope), decreasing followed by increasing trend at the Sedlčany location (the soil depletion on the steepest parts), and increasing trend at the Vidim location (the positive impact of the soil organic content, $\left.C_{o x}\right)$. The slope $\left(S_{I N F}\right)$ of the soil-water retention curve (Figure 4) indicates that while the physical quality of soil at the Brumovice location did not considerably differ along the transect (soils of a very good quality), at the Vidim location decreased with decreasing elevation (i.e., very good at the summit, good at the $3^{\text {rd }}$ and $5^{\text {th }}$ point, and poor at the $2^{\text {nd }}$ and $4^{\text {th }}$ point). It should be noted that different trends in the $S_{I N F}$ values were observed at 5 points of the hillslope transects delineated in two Luvisol (on loess) areas by Fér et al. (2020). While the $S_{I N F}$ values did not considerably differ in the area with a 12-year no-till practice, the lower $S_{I N F}$ values were found at the summit and shoulder and higher $S_{I N F}$ values were measured at the lower positions within the transect in the area with a long-term conventional tillage. This means that distribution of this parameter (as well as other related parameters) with respect to the terrain position cannot be generalized, because it reflects actual field conditions (i.e., degree of soil transformation due to erosion/accumulation processes, actual agricultural practice, etc.). Different trends were also observed for both Cambisols (Figure 4). While the physical quality of soil at the Sedlčany location again did not considerably differ along the transect (soils of a very good quality), at the Železná location decreased at the sloping parts of the transect (i.e., good at the summit and toeslope, and poor at the other parts of the transect). While the very good physical quality at the Brumovice location is related to the well-developed soil structure, at the Sedčany location is related to the coarse texture of these soils. Statistical analyses mostly did not reveal statistically significant relationships between evaluated soil properties. Except at the Brumovice location, the significant relationship was found between WSA and $S_{I N F}(\mathrm{R}=0.898, \mathrm{p}=0.038)$. This means that the physical quality increased with the increasing aggregate stability. Such relationships were not detected for other locations. Though, at the Sedlčany location $S_{I N F}$ was related to the sand content $(\mathrm{R}=$ $0.966, \mathrm{p}=0.007)$. Both correlations confirm previous statements concerning the factor determining a very good physical quality of soil at the Brumovice and Sedlčany locations. Finally, the significant correlation was found between $C_{o x}$ and $S_{I N F}$ $(\mathrm{R}=0.942, \mathrm{p}=0.017)$ for the Vidim location.

\section{Hydraulic conductivities relative to soil properties characterizing soil structure stability and physical quality of soils}

As mentioned above, the measured hydraulic conductivities at each sampling point with some exemptions largely vary (Figure 5). Thus, results of the correlation analyses provide only approximate data for the assessment of possible relationships between the measured hydraulic conductivities and other soil characteristics. Correlations mostly did not reveal statistically significant relationships at the $95 \%$ level and higher. The following relationships were obtained for the Brumovice locality. The $K_{s, M S O}$ values significantly corelated with $P(\mathrm{R}=0.914$, $\mathrm{p}=0.030), \theta_{I N F}(\mathrm{R}=0.951, \mathrm{p}=0.013)$ and $h_{I N F}(\mathrm{R}=-0.880$, $\mathrm{p}=0.049)$, and insignificantly corelated with $W S A(\mathrm{R}=0.814$, $\mathrm{p}=0.094)$ and $C_{o x}(\mathrm{R}=0.877, \mathrm{p}=0.051)$. The $K_{h}=-2, M D I, Z$ values significantly correlated with $\theta_{I N F}(\mathrm{R}=0.986, \mathrm{p}=0.002)$ and $h_{I N F}(\mathrm{R}=-0.920, \mathrm{p}=0.027)$. Statistically insignificant relationships were only found for the $K_{h=-2, M D I, W}$ values and $C_{o x}(\mathrm{R}=0.828, \mathrm{p}=0.083)$ or $\theta_{I N F}(\mathrm{R}=0.954, \mathrm{p}=0.066)$. For the Vidim locality, the $K_{h}=-2, M D I, W$ values significantly corelated with $h_{I N F}(\mathrm{R}=-0.890, \mathrm{p}=0.043)$ and insignificantly with $P$ $(\mathrm{R}=0.871, \mathrm{p}=0.054)$. A statistically insignificant correlation was found between $K_{h=-2, M D I, Z}$ and $h_{I N F}(\mathrm{R}=-0.810, \mathrm{p}=0.097)$. Even fewer relationships were identified for both Cambisol regions. At the Sedlčany locality, the $K_{h=-2, M D I, W}$ values significantly corelated with $S_{I N F}(\mathrm{R}=0.944, \mathrm{p}=0.016)$ and insignificantly correlated with $P(\mathrm{R}=0.847, \mathrm{p}=0.070)$. The $K_{s, G P}$ values significantly corelated with $C_{o x}(\mathrm{R}=0.941, \mathrm{p}=0.017)$. No statistically significant relationship was obtained for the Železná locality. The relationships between $h_{I N F}$ and some of the evaluated conductivities was probably found because this value associates with the pore radius $\left(r_{I N F}=C / h_{I N F}\right.$, where con- 
stant $C$ includes the water density, interfacial tension, contact angle and gravitational acceleration), of the largest frequency, i.e., reflects a soil-pore distribution. The increasing $h_{I N F}$ value thus indicate decreasing size of pores and opposite decreasing $h_{I N F}$ values indicate increasing size of pores. The positive correlations with $P$ and $\theta_{I N F}$ associate with the volume of soil pores. Finally, the positive correlations with $C_{o x}$, WSA and $S_{I N F}$ associates with a quality of soils.

\section{CONCLUSION}

The goal of this this study was to test three hypotheses. The first hypotheses, that trends in the saturated hydraulic conductivities within the hillslope transects obtained with different techniques (MSO and GP) should differ, was proved in all cases. However, various trends in the $K_{s, G P}$ values compared to the $K_{s, M S O}$ values were probably mainly due to the soil-pore deformation during the well preparation, and not so much due to the impact of the diverse character of large gravitation pores. The second hypothesis, that trends in the unsaturated hydraulic conductivities obtained with different techniques (MSO and MDI) should be similar was partly proven only for soils, which were developed on loess substrates. The well-developed soilpore systems of these soils were less impacted by the soil preparation for the MDI tests than those in both Cambisols. The third hypothesis that measured hydraulic conductivities should associate with the soil physical quality and stability of soil structure was also partly proven only for structural soils developed on loess, but not for soils of a weekly developed soil-pore structure as Cambisols. However, it must be noted that study was performed after harvest, i.e., on the most consolidated land. The soil porous systems and associated soil physical and hydraulic properties of arable soils largely vary during the year. Therefore, new studies are needed to test these hypotheses for different stages of a soil structure that develops during the year.

Acknowledgement. Authors acknowledge the financial support of the Ministry of Agriculture of the Czech Republic, Project Soil water regime within a sloping agricultural area (No. QJ1230319), and the European Regional Development Fund, Project Centre for the investigation of synthesis and transformation of nutritional substances in the food chain in interaction with potentially harmful substances of anthropogenic origin: comprehensive assessment of soil contamination risks for the quality of agricultural products (No. CZ.02.1.01/0.0/0.0/16_019/0000845). Authors also thank to Ondřej Jakšík for his help with delineation of transects, field work and data administration, to Veronika Lepešková (Jirků), Zuzana Schmidtová, Adam Kubiš and Karel Němeček for their help in the field and/or laboratory, to Vít Penížek and Tereza Zádorová for their expertise during the locality selection and soil type definition, and to Anna Žigová for taking micromorphological images.

\section{REFERENCES}

Alletto, L., Coquet, Y., 2009. Temporal and spatial variability of soil bulk density and near-saturated hydraulic conductivity under two contrasted tillage management system. Geoderma, 152, 85-94.

Cantón, Y., Solé-Benet, A., Asensio, C., Chamizo, S., Puigdefábregas, J., 2009. Aggregate stability in range sandy loam soils relationships with runoff and erosion. Catena, 77, 192-199.

Centeno, L.N., Timm, L.C., Reichardt, K., Beskow, S., Caldei- ra, T.L., de Oliveira, L.M., Wendroth, O., 2020. Identifying regionalized co-variate driving factors to assess spatial distributions of saturated soil hydraulic conductivity using multivariate and state-space analyses. Catena, 191, 104583.

Chandrasekhar, P., Kreiselmeier, J., Schwen, A., Weninger, T., Julich, S., Feger, K.-H., Schwärzel, K., 2018. Why we should include soil structural dynamics of agricultural soils in hydrological models. Water, 10, 1862.

Dexter, A.R., 2004a. Soil physical quality Part I. Theory effect of soil texture density and organic matter and effect on root growth. Geoderma, 120, 201-214.

Dexter, A.R., 2004b. Soil physical quality Part II. Friability tillage tilth and hard-setting. Geoderma, 120, 215-226.

Dexter, A.R., 2004c. Soil physical quality Part III. Unsaturated hydraulic conductivity and general conclusions about Stheory. Geoderma, 120, 227-239.

Dexter, A.R., Czyz, E.A., 2007. Application of S-theory in study of soil physical degradation and its consequences. Land Degrad. Dev., 18, 369-381.

Elrick, D.E., Reynolds W.D., Tan, K.A., 1989. Hydraulic conductivity measurements in the unsaturated zone using improved well analyses. Ground Water Monit. Rev., 9, 184193.

Fér, M., Kodešová, R., Nikodem, A., Jirků, V., Jakšík, O., Němeček, K., 2016. The impact of the permanent grass cover or conventional tillage on hydraulic properties of Haplic Cambisol developed on paragneiss substrate. Biologia, 71, 10, 1144-1150.

Fér, M., Kodešová, R., Nikodem, A., Jelenová, K., Klement, A., 2018. Influence of soil-water content on $\mathrm{CO}_{2}$ efflux within the elevation transect heavily impacted by erosion. Ecohydrology, 11, 6, e1989.

Fér, M., Kodešová, R., Hroníková, S., Nikodem, A., 2020. The effect of 12-year ecological farming on the soil hydraulic properties and repellency index. Biologia, 75, 795-798.

Florinsky, I.V., Eilers, R.G., Manning, G.R., Fuller, L.G., 2002. Prediction of soil properties by digital terrain modelling. Environ. Model. Softw., 17, 3, 95-311.

Gardner, W.R., 1958. Some steady state solutions of unsaturated moisture flow equations with application to evaporation from a water table. Soil Sci., 85, 228-232.

Gribb, M.M., Kodešová, R., Ordway, S.E., 2004. Comparison of soil hydraulic property measurement methods. J. Geotech. Geoenviron. Eng., 130, 1084-1095.

Grundwald, S. Ed., 2005. Environmental Soil-Landscape Modeling. CRC Press.

Herbst, M., Diekkrüger, B., Vereecken, H., 2006. Geostatistical co-regionalization of soil hydraulic properties in a microscale catchment using terrain attributes. Geoderma, 132, $1-2,206-221$.

IUSS Working Group WRB, 2015. World Reference Base for Soil Resources 2014, update 2015 International soil classification system for naming soils and creating legends for soil maps. World Soil Resources Reports No. 106. FAO, Rome.

Jakšík, O., Kodešová, R., Kubiš, A., Stehlíková, I., Drábek, O., Kapička, A., 2015. Soil aggregate stability within morphologically diverse areas. Catena, 127, 287-299.

Jakšík, O., Kodešová, R., Kapička, A., Klement, A., Fér, M., Nikodem, A., 2016. Using magnetic susceptibility mapping for assessing soil degradation due to water erosion. Soil Water Res., 11, 2, 105-113.

Jirků, V., Kodešová, R., Nikodem, A., Mühlhanselová, M., Žigová, A., 2013. Temporal variability of structure and hydraulic properties of topsoil of three soil types. Geoderma, 204-205, 43-58. 
Kodešová, R., Rohošková, M., Žigová, A., 2009. Comparison of aggregate stability within six soil profiles under conventional tillage using various laboratory tests. Biologia, $64,3,550-554$.

Kodešová, R., Šimůnek, J., Nikodem, A., Jirků, V., 2010. Estimation of parameters of the radially-symmetric dualpermeability model using tension disc infiltrometer and Guelph permeameter experiments. Vadose Zone J., 9, 213225.

Kodešová, R., Jirků, V., Kodeš, V., Mühlhanselová, M., Nikodem, A., Žigová, A., 2011. Soil structure and soil hydraulic properties of Haplic Luvisol used as arable land and grassland. Soil Till. Res., 111, 2, 154-161.

Lark, R.M., Beckett, P.H.T., 1998. A geostatistical descriptor of the spatial distribution of soil classes, and its use in predicting the purity of possible soil map units. Geoderma, 83, 3-4, 243-267.

Lichner, L., Iovino, M., Šurda, P., Nagy, V., Zvala, A., Kollár, J., Pecho, J., Píš, V., Sepehrnia, N., Sándor, R., 2020. Impact of secondary succession in abandoned fields on some properties of acidic sandy soils. J. Hydrol. Hydromech., 68, $1,12-18$.

Mayer, S., Kühnel, A., Burmeister, J., Kögel-Knabner, I., Wiesmeier, M., 2019. Controlling factors of organic carbon stocks in agricultural topsoils and subsoils of Bavaria. Soil Till. Res., 192, 22-32.

Meter Group AG., 2020. Mini Disk Infiltrometer. Mettlacher Straße 8, München. http://publications.metergroup.com/Manuals/20421_Mini_D isk_Manual_Web.pdf

Miller, B.A., Schaetzl, R.J., 2015. Digital classification of hillslope position. Soil Sci. Soc. Am. J., 79, 132-145.

Moore, I.D., Gessler, P.E., Nielsen, G.A., Peterson, G.A., 1993. Soil attribute prediction using terrain analysis. Soil Sci. Soc. Am. J., 57, 443-452.

Mualem, Y., 1976. A new model for predicting the hydraulic conductivity of unsaturated porous media. Water Resour. Res., 12, 3, 513-522.

Nikodem, A., Kodešová. R., Fér, M., Klement, A., 2021. Using scaling factors for characterizing spatial and temporal variability of soil hydraulic properties of topsoils in areas heavily affected by soil erosion. J. Hydrol., 593, 125897.

Nimmo J.R., Perkins K.S., 2002. Aggregate stability and size distribution. In: Dane, J.H., Topp, G.C. (Eds.): Methods of Soil Analysis, Part 4 - Physical Methods. SSSA, Madison, pp. 317-328.

Papanicolaou, A.N., Elhakeem, M., Wilson, C.G., Burras, C.L., West, L.T., Lin, H., Clark, B., Oneal, B.E., 2015. Spatial variability of saturated hydraulic conductivity at the hillslope scale: Understanding the role of land management and erosional effect. Geoderma, 243-244, 58-68.

Pavlů, L., Kodešová, R., Fér, M., Nikodem, A., Němec, F., Prokeš, R, 2021. The impact of various mulch types on soil properties controlling water regime of the Haplic Fluvisol. Soil Till. Res., 205, 104748.

Penížek, V., Zádorová, T., Kodešová, R., Vaněk, A., 2016. Influence of elevation data resolution on spatial prediction of colluvial soils in a luvisol region. PloS ONE, 11, 11, 165699.

Pennock, D.J., 2003. Terrain attributes, landform segmentation, and soil redistribution. Soil Till. Res., 69, 15-26.

Reynolds, W.D., Elrick, D.E., 1991. Determination of hydraulic conductivity using a pension infiltrometer. Soil Sci. Soc. Am. J., 55, 633-639.

Reynolds, W.D., Elrick D.E., Youngs, E.G., Amoozegar, A.,
Booltink, H.W.G., Bouma, J., 2002. Saturated and fieldsaturated water flow parameters. In: Dane, J., Topp, C. (Eds.): Methods of Soil Analysis. Part 4: Physical Methods. Soil Science Society of America, Inc., Madison, USA, pp. 797-878.

Romano, N., Palladino, M., 2002. Prediction of soil water retention using soil physical data and terrain attributes. J. Hydrol., 265, 1-4, 56-75.

Sagova-Mareckova, M., Zadorova, T., Penizek, V., Omelka, M., Tejnecky, V., Pruchova, P., Chuman, T., Drabek, O., Buresova, A., Vanek, A., Kopecky, J., 2016. The structure of bacterial communities along two vertical profiles of a deep colluvial soil. Soil Biol. Biochem., 101, 65-73.

Sándor, R., Iovino, M., Lichner, L., Alagna, V., Forster, D., Fraser, M., Kollár, J., Šurda, P., Nagy, V., Szabó, A., Fodor, N., 2021. Impact of climate, soil properties and grassland cover on soil water repellency. Geoderma, 383, 114780.

Sarapatka, B., Cap, L., Bila, P., 2018. The varying effect of water erosion on chemical and biochemical soil properties in different parts of Chernozem slopes. Geoderma, 314, 20-26.

Sepehrnia, N., Woche, S.K., Goebel, M.-O., Bachmann, J., 2020. Development of a universal microinfiltrometer to estimate extent and persistence of soil water repellency as a function of capillary pressure and interface chemical composition. J. Hydrol. Hydromech., 68, 4, 392-403.

Schwen, A., Bodner, G., Loiskandl, W., 2011a. Time-variable soil hydraulic properties in near-surface soil water simulations for different tillage methods. Agric. Water Manag., 99, $42-50$.

Schwen, A., Bodner, G., Scholl, P., Buchan, G., Loiskandl, W., 2011 b. Temporal dynamic of soil hydraulic properties and the water-conducting porosity under different tillage. Soil Till. Res., 113, 89-98.

Sobieraj, J.A., Elsenbeer, H., Coelho, R.M., Newton, B., 2002. Spatial variability of soil hydraulic conductivity along a tropical rainforest catena. Geoderma, 108, 1-2, 79-90.

Soilmoisture Equipment Corp. 2012. Model 2800K1 Guelph Permeameter Operating Instructions. Soilmoisture Equipment Corp., Santa Barbara, CA. https://www.soilmoisture.com/pdfs/Resource Instructions 0 898-2800_2800K1\%20Guelph\%20Permeameter\%20.pdf

StatSoft Inc., 2013. STATISTICA (data analysis software system) version 12. www.statsoft.com

Stoops, G., 2003. Guidelines for Analysis and Desription of Soils and Regolith Thin Sections. Soil Science Society of America, Inc. Madison, Wisconsin, USA, 184 p.

van Dam, J.C., Stricker, J.M.N., Droogers, P., 1994. Inverse method to determine soil hydraulic function from multi-step outflow experiment. Soil Sci. Soc. Am. J., 58, 3, 647-652.

van Genuchten, M.Th., 1980. A closed-form equation for predicting the hydraulic conductivity of unsaturated soils. Soil Sci. Soc. Am. J., 44, 5, 892-898.

Vašát, R., Kodešová, R., Borůvka, L., Klement, A., Jakšík, O., Gholizadeh, A., 2014. Consideration of peak parameters derived from continuum-removed spectra to predict extractable nutrients in soils with visible and near-infrared diffuse reflectance spectroscopy (VNIR-DRS). Geoderma, 232-234, 208-218.

Vašát, R., Kodešová, R., Borůvka, L., Jakšík, O., Klement, A., Drábek, O., 2015a. Absorption features in soil spectra assessment. Appl. Spectrosc., 69, 12, 1425-1431.

Vašát, R., Kodešová, R., Klement, A., Jakšík, O., 2015 b. Predicting oxidizable carbon content via visible- and nearinfrared diffuse reflectance spectroscopy in soils heavily affected by water erosion. Soil Water Res., 10, 2, 74-77. 
Vašát, R., Kodešová, R., Borůvka, L., 2017a. Ensemble predictive model for more accurate soil organic carbon spectroscopic estimation. Comput. Geosci., 104, 75-83.

Vašát, R., Kodešová, R., Borůvka, L., Jakšík, O., Klement, A., Brodský, L., 2017b. Combining reflectance spectroscopy and the digital elevation model for soil oxidizable carbon estimation. Geoderma, 303, 133-142.

Vašát, R., Kodešová, R., Klement, A., Borůvka, L., 2017 c. Simple but efficient signal pre-processing in soil organic carbon spectroscopic estimation. Geoderma, 298, 46-53.

Villarreal, R., Lozano, L.A., Salazar, M.P., Bellora, G.L., Melani, E.M., Polich, N., Soracco, C.G., 2020. Pore system configuration and hydraulic properties. Temporal variation during the crop cycle in different soil types of Argentinean Pampas Region. Soil Till. Res., 198, 104528.

Watson, K.W., Luxmoore, R.J., 1986. Estimating macroporosity in a forest watershed by use of a tension infiltrometer. Soil Sci. Soc. Am. J., 50, 578-582.

Wooding, R.A., 1968. Steady infiltration from a shallow circular pond. Water Resour. Res., 4, 1259-1273.

Zádorová, T., Penížek, V., Šefrna, L., Rohošková, M., Borůvka, L., 2011a. Spatial delineation of OC-rich Colluvial soils in Chernozem regions by terrain analysis and fuzzy classification. Catena, 85, 22-33.

Zádorová, T., Jakšík, O., Kodešová, R., Penížek, V., 2011 b. Influence of terrain attributes and soil properties on soil aggregate stability. Soil Water Res., 6, 111-119.
Zádorová, T., Penížek, V., Šefrna, L., Drábek, O., Mihaljevič, M., Volf, Š., Chuman, T., 2013. Identification of Neolithic to modern erosion-sedimentation phases using geochemical approach in a loess covered sub-catchment of South Moravia, Czech Republic. Geoderma, 195-196, 56-69.

Zádorová, T., Žížala, D., Peňížek, V., Čejková, Š., 2014. Relating extent of colluvial soils to topographic derivatives and soil variables in a Luvisol sub-catchment, central Bohemia, Czech Republic. Soil Water Res., 2, 47-57.

Zádorová, T., Penížek, V., Vašát, R., Žížala, D., Chuman, T., Vaněk, A., 2015. Colluvial soils as a soil organic carbon pool in different soil regions. Geoderma, 253-254, 122-134.

Zádorová, T., Penížek, V., 2018. Formation, morphology and classification of colluvial soils: a review. Eur. J. Soil Sci., 69, 577-591.

Zhang, R., 1997. Determination of soil sorptivity and hydraulic conductivity from the disk infiltrometer. Soil Sci. Soc. Am. J., 61, 1024-1030.

Zhang, Z.F., Groenevelt, P.H., Parkin, G.W., 1998. The wellshape factor for the measurement of soil hydraulic properties using the Guelph permeameter. Soil Till. Res., 49, 219-221.

Received 4 February 2021 Accepted 29 March 2021 